$\Phi=$ 囯

\title{
In vitro callus induction of gerbera from leaf explant
}

\author{
Sadia Afrin Jui ${ }^{1 *}$, Md. Mijanur Rahman Rajib ${ }^{2}$, M. Mofazzal Hossain ${ }^{3}$, Sharmila \\ Rani Mallik ${ }^{4}$, Iffat Jahan Nur ${ }^{5}$, Jannatul Ferdush ${ }^{6}$ \\ ${ }^{1}$ Scientific Officer, Bangladesh Jute Research Institute \\ ${ }_{2}^{2}$ Associate Professor, Bangabandhu Sheikh Mujibur Rahman Agricultural University \\ ${ }^{3}$ Professor, Bangabandhu Sheikh Mujibur Rahman Agricultural University \\ ${ }^{4}$ Scientific Officer, Bangladesh Agricultural Research Institute \\ ${ }^{5}$ Scientific Officer, Bangladesh Jute Research Institute \\ ${ }^{6}$ Scientific Officer, Bangladesh Jute Research Institute \\ *Corresponding author E-mail: sadiabsmru@gmail.com
}

\begin{abstract}
The experiment was designed to evaluate the effect of growth regulators on leaf explant of Gerbera for callus induction. Various kinds of plant growth regulators such as 6-Benzylaminopurine (BAP), $\alpha$-Naphthalene acetic acid (NAA), 2, 4-Dichlorophenoxyacetic acid (2, 4D), Indole-3-acetic acid (IAA) were used to initiate cultures. These were added to Murashige and Skoog medium in different combinations and concentrations. Leaf explants cultured on MS medium supplemented with BAP+ 2, 4-D+ IAA in T4 treatment \& BAP+2,4-D in T5 treatment showed the best results for callus induction. On the other hand callus was induced early in the combination of BA+2,4-D + IAA hormone in T5, T9 \& T8 treatment respectively. The rate of callus induction was very low in BA + NAA combinations but it was much earlier.
\end{abstract}

Keywords: Callus, Gerbera, Growth Regulators, Leaf Explants, Culture.

\section{Introduction}

Gerbera (Gerbera jamesonii Bolus) belongs to the family Asteraceae is an herbaceous perennial flower crop, with long stalks and daisylike flower, a native of South Africa. It was named in honor of the German botanist and naturalist Traugott Gerber. It has approximately 30 species in the wild, extending to South America, Africa and tropical Asia. Variety in color has made this flowering plant attractive for use in garden decorations and for cut flowers as it has a long vase life (Bose et al., 2003; Chung et al., 2005; Chauhan, 2004). Gerbera is very popular and is the fifth most widely used cut flower in the world after rose, carnation, chrysanthemum, and tulip. It has great potential for local as well as export market. Cultivation of flower is reported to give 3-5 times and 1.5-2.0 times more returns than obtained from rice and vegetable cultivation, respectively (Dadlani, 2003). The most commercial cultivars are propagated through vegetative means by multiplication through divisions of clumps; however, the multiplication by this method is too slow to be commercially viable as well as seedlings derived from this way is not good quality. To commercialize this crop and to meet the growing demand for planting material, tissue and organ culture techniques are being used as alternative methods for propagation in many countries. Callus induction is the first \& very important step which leads to plant regeneration in large scale. Plant callus is a growing mass of unorganized plant parenchyma cell. Leaf explants are easy to sterilize than other explants \& contamination rate is very low. This experiment was carried out to develop a protocol for in-vitro callus formation of gerbera for future conservation.

\section{Materials and methods}

The experiment was conducted in tissue culture laboratory of the Department of Horticulture, Bangabandhu Sheikh Mujibur Rahman Agricultural University, Gazipur from November 2014 to July 2015. Tender leaves of gerbera were collected from Horticultural nursery of BSMRAU, Gazipur. The leaves (4-6 mm) were washed with detergent Tween 20 for $4-5$ min. and then sterilized with $0.1 \% \mathrm{HgCl}_{2} \mathrm{for}$ 3-4 min and washed thoroughly with sterilized water to remove the chemicals. For callus induction, the explants were cultured on Murashige and Skoog (MS) medium supplemented with different concentrations and combinations of growth regulators as described below. The cultures without growth regulators served as control. The cultures were maintained at $25+2^{\circ} \mathrm{C}$ in dark. The data were recorded on days required to callus formation and percent explants produced callus. The Following combinations of growth regulators were used 


\begin{tabular}{llll} 
& Combination 1 & \\
\hline Treatment & BAP $(\mathrm{ppm})$ & $2,4-\mathrm{D}(\mathrm{ppm})$ & IAA $(\mathrm{ppm})$ \\
\hline $\mathrm{T}_{1}$ & 0 & 0 & 0 \\
$\mathrm{~T}_{2}$ & 1 & 1.5 & 1.0 \\
$\mathrm{~T}_{3}$ & 1 & 1.5 & 1.5 \\
$\mathrm{~T}_{4}$ & 1 & 2.5 & 1.0 \\
$\mathrm{~T}_{5}$ & 1 & 2.5 & 1.5 \\
$\mathrm{~T}_{6}$ & 2 & 1.5 & 1.0 \\
$\mathrm{~T}_{7}$ & 2 & 1.5 & 1.5 \\
$\mathrm{~T}_{8}$ & 2 & 2.5 & 1.0 \\
$\mathrm{~T}_{9}$ & 2 & 2.5 & 1.5 \\
\hline
\end{tabular}

\begin{tabular}{lll}
\multicolumn{2}{c}{ Combination 2 } \\
\hline \multicolumn{1}{c}{ Treatment } & BAP $(\mathrm{ppm})$ & $2,4-\mathrm{D}(\mathrm{ppm})$ \\
\hline $\mathrm{T}_{1}$ & 0 & 0 \\
$\mathrm{~T}_{2}$ & 0 & 1.5 \\
$\mathrm{~T}_{3}$ & 0 & 2.5 \\
$\mathrm{~T}_{4}$ & 1 & 0 \\
$\mathrm{~T}_{5}$ & 1 & 1.5 \\
$\mathrm{~T}_{6}$ & 1 & 2.5 \\
$\mathrm{~T}_{7}$ & 2 & 0 \\
$\mathrm{~T}_{8}$ & 2 & 1.5 \\
$\mathrm{~T}_{9}$ & 2 & 2.5 \\
\hline
\end{tabular}

\begin{tabular}{llcl}
\multicolumn{1}{c}{ Combination 3 } \\
\hline Treatment & BA $(\mathrm{ppm})$ & $2,4-\mathrm{D}(\mathrm{ppm})$ & IAA (ppm) \\
\hline $\mathrm{T}_{1}$ & 0 & 0 & 0 \\
$\mathrm{~T}_{2}$ & 1 & 1.5 & 1.0 \\
$\mathrm{~T}_{3}$ & 1 & 1.5 & 1.5 \\
$\mathrm{~T}_{4}$ & 1 & 2.5 & 1.0 \\
$\mathrm{~T}_{5}$ & 1 & 2.5 & 1.5 \\
$\mathrm{~T}_{6}$ & 2 & 1.5 & 1.0 \\
$\mathrm{~T}_{7}$ & 2 & 1.5 & 1.5 \\
$\mathrm{~T}_{8}$ & 2 & 2.5 & 1.0 \\
$\mathrm{~T}_{9}$ & 2 & 2.5 & 1.5 \\
\hline
\end{tabular}

Combination 4

\begin{tabular}{lll}
\hline Treatment & BA $(\mathrm{ppm})$ & NAA $(\mathrm{ppm})$ \\
\hline $\mathrm{T}_{1}$ & 0 & 0 \\
$\mathrm{~T}_{2}$ & 4 & 1 \\
$\mathrm{~T}_{3}$ & 5 & 1 \\
$\mathrm{~T}_{4}$ & 6 & 1 \\
$\mathrm{~T}_{5}$ & 4 & 2 \\
$\mathrm{~T}_{6}$ & 5 & 2 \\
$\mathrm{~T}_{7}$ & 6 & 2 \\
\hline
\end{tabular}

\section{Results and discussion}

\subsection{BAP, 2, 4-D and IAA}

The result of callus induction in response of different concentration of growth hormone (BAP, 2,4-D, IAA) are presented in Table $\mathbf{1}$. Among the nine treatments, callus induction days ranges from 47-59.67and Percentages of callus initiation ranges from (49-86\%). Higher days were required in treatment $\mathrm{T}_{9}(59.5)$ and $\mathrm{T}_{8}(59.5)$ and the lower were in $\mathrm{T}_{5}(47)$ and $\mathrm{T}_{9}(50.8)$. Percentages of callus formation are higher in $\mathrm{T}_{4}(85.5)$ and lower in $\mathrm{T}_{5}$ (49.65) and $\mathrm{T}_{6}$ (50.8). Paduchuri et al. (2010) reported that highly efficient and reproducible callus induction protocol for Gerbera jamesonii has been developed using leaves as explant source. The optimal callus was developed on Murashige and Skoog (MS) basal medium supplemented with BAP 2mg/L + Kinetin $1 \mathrm{mg} / \mathrm{L}+\mathrm{NAA} 2 \mathrm{mg} / \mathrm{L}+2,4-\mathrm{D} 2.5 \mathrm{mg} / \mathrm{L}$.

Table 1: Effect of Different Concentration of BAP, 2, 4-D and IAA on Callus Induction

\begin{tabular}{lll}
\hline Treatment & Callus initiation (Days) & Callus initiation (\%) \\
\hline $\mathrm{T}_{1}$ & - & - \\
$\mathrm{T}_{2}$ & 59 & 75.25 \\
$\mathrm{~T}_{3}$ & 55 & 65 \\
$\mathrm{~T}_{4}$ & 50.8 & 85.5 \\
$\mathrm{~T}_{5}$ & 47 & 49.65 \\
$\mathrm{~T}_{6}$ & 50 & 50.8 \\
$\mathrm{~T}_{7}$ & 57.5 & 60.57 \\
$\mathrm{~T}_{8}$ & 59.5 & 60 \\
$\mathrm{~T}_{9}$ & 59.67 & 70.25 \\
$\% \mathrm{CV}$ & $9.14 \%$ & $18.80 \%$ \\
\hline
\end{tabular}

\subsection{BAP, 2, 4-D}

The number of days required for callus induction ranges from (33-39) days and induction percentage ranges from 40-100 in (Table 2). Maximum number of days were required in $\mathrm{T}_{4}$ (39) followed by $\mathrm{T}_{6}(35.75)$ and minimum were in $\mathrm{T}_{8}(33.67)$. Percentages of callus initiation were higher in $\mathrm{T}_{5}(86)$ and lower in $\mathrm{T}_{9}$ (46.68). Hasbullah et al., (2008) observed that leaf explants cultured on MS medium supplemented with $1.0 \mathrm{mg} \mathrm{L}^{-1} \mathrm{BAP}$ and $2.0 \mathrm{mg} \mathrm{L}^{-1} 2,4-\mathrm{D}$ showed the best results for callus induction. 
Table 2: Effect of Different Concentration of BAP, 2, 4-D on Callus Induction

\begin{tabular}{lll}
\hline Treatment & Callus initiation (Days) & Callus initiation (\%) \\
\hline $\mathrm{T}_{1}$ & - & - \\
$\mathrm{T}_{2}$ & - & - \\
$\mathrm{T}_{3}$ & - & - \\
$\mathrm{T}_{4}$ & 39 & 61 \\
$\mathrm{~T}_{5}$ & 34.8 & 86 \\
$\mathrm{~T}_{6}$ & 35.75 & 64.67 \\
$\mathrm{~T}_{7}$ & 34.5 & 65.1 \\
$\mathrm{~T}_{8}$ & 33.67 & 59.72 \\
$\mathrm{~T}_{9}$ & 35 & 46.68 \\
$\% \mathrm{CV}$ & $5.25 \%$ & $19.91 \%$ \\
\hline
\end{tabular}

\subsection{BA, 2, 4-D and IAA}

Among various treatment (Table 3), the number of days required for callus induction ranges from (28.75-394.6) days and percentages of callus initiation ranges from (22.22-55.56) \%. Explant treated with $\mathrm{T}_{2}$ requires maximum days (34.6 days) for callus induction and minimum were in $\mathrm{T}_{3}$ (28.35 days). Callus induction percent were higher in $\mathrm{T}_{2}(55.56)$ and $\mathrm{T}_{7}(55.56)$ respectively and it was lower in $\mathrm{T}_{9}$ $(33.35 \%)$. Satyavani et al. (2011) reported that maximum number of callus are induced from stem explants on MS medium enriched with $0.5 \mathrm{mg} \mathrm{L}^{-1}$ IAA, 2,4-D and 1 ppm of 6-BA in case of bitter Apple Tissue culture.

Table 3: Effect of Different Concentration of BA, 2, 4-D and IAA on Callus Induction

\begin{tabular}{lll} 
& Table 3: Effect of Different Concentration of BA, 2, 4-D and IAA on Callus Induction \\
\hline Treatment & Callus initiation (Days) & Callus initiation (\%) \\
\hline $\mathrm{T}_{1}$ & - & - \\
$\mathrm{T}_{2}$ & 34.6 & 55.56 \\
$\mathrm{~T}_{3}$ & 28.75 & 44.44 \\
$\mathrm{~T}_{4}$ & 34.25 & 44.44 \\
$\mathrm{~T}_{5}$ & 29.25 & 44.44 \\
$\mathrm{~T}_{6}$ & - & - \\
$\mathrm{T}_{7}$ & 32.2 & 55.56 \\
$\mathrm{~T}_{8}$ & - & - \\
$\mathrm{T}_{9}$ & 30.5 & 33.35 \\
$\mathrm{CV} \%$ & $7.91 \%$ & $18.06 \%$ \\
\hline
\end{tabular}

\subsection{BA and NAA}

The rate of callus induction in BA and NAA was very low. Among the seven treatments (Table 4), only T 3 andT 4 produces callus. Day's requirement of callus induction is 24 and 25.5 respectively and percentage was only 33.33 and 42.44 respectively. Kumar and Kanwar (2006) observed callus induction on leaf and petal explants on MS medium supplemented with 1, 1.5 and 2 mg/dm3 2,4-D. BA and kinetin failed to induce callus on leaf and petal explants in cut flower gerbera.

\begin{tabular}{|c|c|c|}
\hline 0Treatment & Callus initiation (Days) & Callus initiation (\%) \\
\hline $\mathrm{T}_{1}$ & - & - \\
\hline $\mathrm{T}_{2}$ & - & - \\
\hline $\mathrm{T}_{3}$ & 24 & 33.33 \\
\hline $\mathrm{T}_{4}$ & 25.5 & 42.44 \\
\hline $\mathrm{T}_{5}$ & - & - \\
\hline $\mathrm{T}_{6}$ & - & - \\
\hline $\mathrm{T}_{7}$ & - & - \\
\hline
\end{tabular}

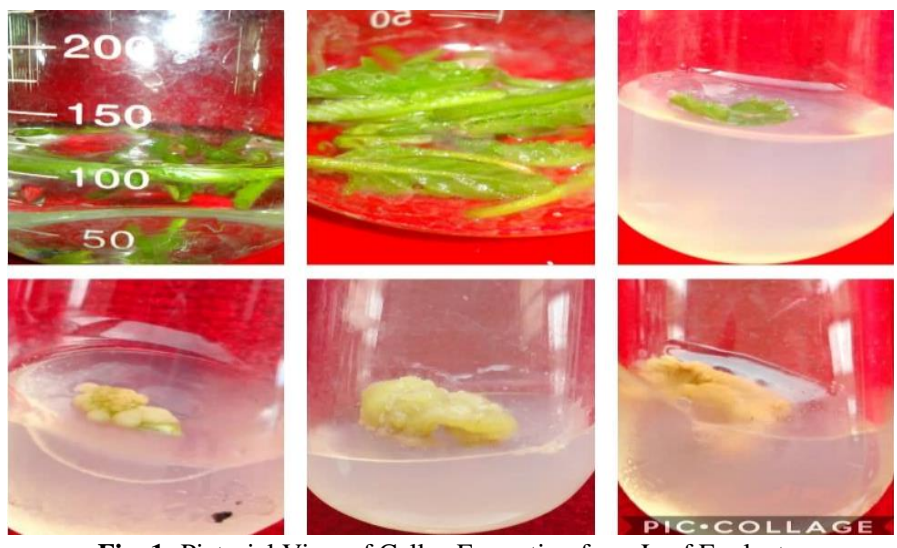

Fig. 1: Pictorial View of Callus Formation from Leaf Explants.

\section{Conclusion}

Different combinations of BA (4-6 ppm), BAP (0-2ppm), 2, 4-D (0-2.5 ppm), IAA (0-1.5ppm) and NAA (1-2 ppm) were used for invitro callus formation of gerbera from leaf explants. The highest $(86 \%)$ callus initiation was started from BAP $(1 \mathrm{ppm})+2,4-\mathrm{D}(1.5 \mathrm{ppm})$ 
within 34.8 days compare to BAP $(1 \mathrm{ppm})+2$,4-D (2.5 ppm) + IAA (1 ppm) within 50.8 days. Although lower percent callus initiation started from BA $(6 \mathrm{ppm})+$ NAA $(1 \mathrm{ppm})$ but it was much earlier (25.5 days).

\section{Conflict of interest statement}

Authors do not have any possible conflicts of interest.

\section{Acknowledgements}

The author expressed her deepest gratefulness to all the members of Horticulture department of BSMRAU for their inspiration and kind supports. The author also expressed her heartiest gratitude to all co-authors for their important technical as well as practical assistance in data collection, analysis and reporting regarding this research work.

\section{References}

[1] Bose, T.K., Yadav, L.P., Pal, P., Pathasarathy, V.P. and Das, P. 2003. Commercial flowers (2nd Ed.). Naya Udyog, Calcutta, India.

[2] Chuahan, N. 2004. Performance of gerbera genotypes under protected cultivation. M.Sc. (Agriculture) Thesis, University of Agricultural Science, Dharwad.

[3] Chung, Y.M., Yi, Y.B. Cho, Y.C., Kim, J.B. and Kwon, O.C. 2005. A new high-yielding red cut flower gerbera cultivar with strong peduncle, Misty Red. Korean Journal of Breeding Science. 37(4): 273-274.

[4] Dadlani, N.K. 2003. Global Positioning of Bangladesh Floriculture. A paper presented in International Floriculture Conference on 6th November 2003, BARC, Farmgate, Dhaka.

[5] Hasbullah, N.A., Taha, R.M. and Awal A. 2008. Growth Optimization and Organogenesis of Gerbera jamesonii Bolus ex. Hook f. in vitro. Pakistan Journal of Biological Sciences. 11 (11): 1449-1454. https://doi.org/10.3923/pjbs.2008.1449.1454.

[6] Kumar, S. and. Kanwar, J. K. 2006. Regeneration ability of petiole, leaf and petal explants in gerbera cut flower cultures in vitro. Folia Horticulture, 18: 57-64.

[7] Paduchuri, P.Y.; Deogirkar, G.V., Kamdi, S. R., Kale, M. C. and Madhavi, D. R. 2010. In vitro callus induction and root regeneration studies in Gerbera jamesonii. International J. Advanced Biotech. and Res., 1 (2): 87-90.

[8] Satyavani, k., Ramanathan, T., Gurudeeban, S. 2011. Effect of Plant Growth Regulators on Callus Induction and Plantlet Regeneration of Bitter Apple (Citrullus colocynthis) from Stem Explant. Asian Journal of Biotechnology. 3 (3): 246-253. https://doi.org/10.3923/ajbkr.2011.246.253. 